\title{
Isolation, purification and functional characterization of fibrinolytic Protease from an Earthworm Eisenia foetida
}

\author{
Faiz Ahmad Joyia ${ }^{1 *}$, Muhammad Anjum Zia ${ }^{2}$, Ghulam Mustafa ${ }^{1}$, \\ Arusha Faheem ${ }^{1}$, Hafiza Taskeen Raana ${ }^{1}$ and Muhammad Sarwar \\ $\mathrm{Khan}^{1}$ \\ 1. Centre of Agricultural Biochemistry and Biotechnology (CABB), University of Agriculture, Faisalabad- \\ Pakistan \\ 2. Department of Biochemistry, University of Agriculture, Faisalabad-Pakistan \\ *Corresponding author's email: faizahmad1980@gmail.com \\ Citation \\ Faiz Ahmad Joyia, Muhammad Anjum Zia, Ghulam Mustafa, Arusha Faheem, Hafiza Taskeen Raana and \\ Muhammad Sarwar Khan. Isolation, purification and functional characterization of fibrinolytic Protease from an \\ Earthworm Eisenia foetida. Pure and Applied Biology. Vol. 7, Issue 2, pp906-909. \\ http://dx.doi.org/10.19045/bspab.2018.700110
}

\begin{tabular}{llll}
\hline \hline Received: 03/05/2018 & Revised: 24/06/2018 & Accepted: 26/06/2018 & Online First: 30/06/2018 \\
\hline \hline
\end{tabular}

\section{Abstract}

Thrombosis (development of clots in blood vessels) may cause vascular blockade culminating into serious consequences broadly known as cardiovascular diseases (CVDs). CVDs are causing more than $31 \%$ of total deaths globally. 'Thrombolysis' is the term used for dissolution of such blood clots. Numerous protein molecules called thrombolytics mediate the process of thrombolysis. Such thrombolytics are not only expensive but also cause non-specific fibrinolysis as the main side-effect, instigating excessive internal bleeding (haemorrhage) and substantial blood loss ultimately leading to death. On the other hand, lumbrokinase (LK), an earthworm-derived fibrinolytic agent being very specific, dissolves fibrin itself or convert plasminogen to plasmin by inducing endogenous tissue plasminogen activator (t-PA) to degrade fibrin clots without any ill-effects. In present study we describe the isolation of a fibrinolytic protease namely Lumbrokinase from indigenous earthworm Eisenia foetida. Protein precipitation was carried out by using various concentrations of $\left(\mathrm{NH}_{4}\right)_{2} \mathrm{SO}_{4}$, desalted and concentrated by dialysis and purified by gel filtration chromatography. Furthermore, its kinetic characterization and in vitro estimation of caseinolytic activity was carried out. Characterization of earthworm-derived fibrinolytic enzyme reveals that it can serve as an ideal therapeutic molecule for oral delivery in CVD patients.

Keywords: Fibrinolysis; Lumbrokinase; Earthworm; Purification; Enzyme activity

\section{Introduction}

It has been reported by Heart Disease and Stroke Statistics that one out of every 3 individuals is suffering from heart problem, which makes cardiovascular diseases (CVDs) the leading cause of death around the globe with 17.7 million mortalities per anum. On an average $79.66 \%$ fatalities resulted from CVDs collectively, as contribution of deaths from strokes was 6.7 million and coronary heart diseases was 7.4 million [1]. Most of the deaths were reported in low income countries due to unhealthy living, food security issues and poor medical facilities. Hence, CVDs have long been rated as top killer disease posing huge burden on world economy [2]. 
Cardiovascular diseases are primarily characterized by formation of clots in blood vessels, which are degraded by the healthy metabolic system to facilitate effective blood circulation [3]. Thrombosis (formation of blood clots) occurs when blood cells particularly platelets are entrapped in a proteinaceous matrix termed as 'fibrin' [4]. The enzymes involved in the dissolution of thrombus are fibrinolytic agents and the process is known as fibrinolysis. However, if the body fails to maintain homeostasis between hemostasis and fibrinolysis, the conditions like stroke, deep vein thrombosis and myocardial infraction occur. In these circumstances the patient is subjected to medication, which usually involves administration of artificial thrombolytic agents like streptokinase, urokinase, Anisolated Plasminogen Streptokinase Activator Complex (APSAC) and other tissue type plasminogen activators [3].

These anticoagulants are inaccessible for poor patients due to high cost on one hand and cause non-specific fibrinolysis on the other hand [5]. As over dose of artificial fibrinolytic drugs have hazardous drawbacks like internal bleeding and heavy blood loss which becomes fatal in most of the cases [6]. Contrary to this, a serine protease derived from earthworm Eisenia foetida was identified to have strong fibrinolytic characteristics. Earthworms in powdered form have been used as a thrombolytic agent over hundred years in ancient China, Japan and Korea to cure diseases related to cardiovascular systems. Lumbrokinases (LKs) isolated from earthworm remained centre of interest due to their fibrinolytic, anti-oxidative, and anti-bacterial properties [7] without adverse effects on cardiovascular system, nervous system, lungs, kidneys and liver.

The chances of non-specific fibrinolysis are eliminated because lumbrokinase precisely targets fibrin clots. These earthworm fibrinolytic enzymes (EFEs) lessen platelet coagulation and prevent thrombosis without blood loss [8]. The mode of action involves direct dissolution of fibrin or it can induce endogenous tissue plasminogen activator (t-PA) which converts plasminogen to plasmin $[9,10]$. Moreover, Lumbrokinases are the only fibrinolytic agents reported for oral administration as they are known to be absorbed by intestinal epithelium in stable and active form [11]. Hence, they are easy to administer and preferable over artificial fibrinolytic agents.

\section{Materials and methods}

Here we describe the extraction, partial purification and characterization of Lumbrokinase from indigenously isolated earthworm specie of Pakistan. Lumbrokinase was isolated from an indigenously isolated earthworm specie Eisenia foetida. About 50 grams of freshly isolated earthworms were carefully rinsed with clean water. Earthworms were soaked in distilled water for 10-12 hours under day light conditions to evacuate casts from their digestive tract. Then earthworms were thoroughly homogenized, and the homogenate was incubated for autolysis at $45^{\circ} \mathrm{C}$ for 4 hours. Afterwards, $0.025 \%$ sodium azide was added to homogenate for further autolysis for a period of 15 days. The autolysed mixture was centrifuged $(4500 \times \mathrm{g})$ at $4^{\circ} \mathrm{C}$ for 30 minutes. The supernatant was collected and filtered through suction pump and cell free extract was subjected to ammonium sulphate precipitation and dialysis. Dialyzed crude proteins were subjected to gel filtration chromatography for partial purification of Lumbrokinase.

Casein hydrolysis method was employed to determine fibrinolytic activity of partially purified LK by making necessary amendments in the protocol described by [11]. In that method $2.0 \mathrm{ml}$ of $4 \%$ casein solution was prepared in $67 \mathrm{mM}$ sodium phosphate buffer ( $\mathrm{pH}$ 7.4). Afterwards, $0.2 \mathrm{ml}$ of purified enzyme extract was added and incubated at $37^{\circ} \mathrm{C}$ for $30 \mathrm{~min}$. The reaction was stopped by adding $6 \mathrm{ml}$ of $15 \%$ trichloroacetic acid (TCA) for another half an hour. The proteolytic activity of 
Lumbrokinase was analysed by spectrophotometer at $280 \mathrm{~nm}$.

Lastly, the extracted lumbrokinase was examined for various physical and chemical properties including different incubation temperatures $\left(40-70^{\circ} \mathrm{C}\right)$, stability at wide $\mathrm{pH}$ range (2-13), concentrations of $0.2 \mathrm{M}$ phosphate buffer, effect of substrate quantity ranging from $0-4 \%$, enzymatic concentration $0-3 \mathrm{ml}$ and incubation time varying from 0-72 hours. The consequences of above mentioned parameters on enzyme activity, were identified by casein assay demonstrated by [12].

\section{Results and discussion}

The maximum specific activity of the isolated enzyme was calculated as 1.122 $\mathrm{U} / \mathrm{mg}$ against casein substrate with $27.5 \%$ protein content. The crude extracts of enzyme were precipitated by using ammonium sulphate salt crystals. The pellet was obtained by continuous addition of ammonium sulphate up to $30 \%$, This concentration was gradually increased to $60 \%$ in which no pellet was observed. However, pellets were recorded in both $30 \%$ and $60 \%$ concentrations by [13].

In order to remove maximum salt and impurities dialysis was conducted, then $22 \mathrm{~g}$ ammonium sulphate residue containing lumbrokinase was collected. The specific activity calculated this time against casein substrate was $18.7 \mathrm{U} / \mathrm{mg}$ with $89.5 \%$ protein, though the recordings were slightly different from Cho et al. 2004 who observed specific activity on casein around $17.3 \mathrm{U} / \mathrm{mg}$ having $94.7 \%$ protein content. The crude enzyme was then filtered and purified via gel filtration chromatography.

Earlier, various parameters of protease activity have been reported [13]. Our studies also showed $100 \%$ enzymatic activity at $50^{\circ} \mathrm{C}$ for 3 hours, when incubated over various range of temperature from 40 $65^{\circ} \mathrm{C}$. It was observed that casein degradation was gradually reduced at $55^{\circ} \mathrm{C}$ showing $85 \%$ lumbrokinase activity. As the temperature raised upto $60^{\circ} \mathrm{C}$ there was significant decrease in proteolytic activity and it was completely lost at $65^{\circ} \mathrm{C}$.
Optimum $\mathrm{pH}$ from lumbrokinase was also estimated by subjecting it to various buffers. It was observed that enzymatic activity was lost at $\mathrm{pH} 2$ but very high 80 $90 \%$ at $\mathrm{pH} 3$, while $\mathrm{pH}$ range of 4-12 was also optimum for enzymatic activity and stability. It was also found that fibrinolysis by this serine protease was increased with long incubation periods. However, our results showed best proteolytic activity during incubation of 28 hours.

It is evident from various studies that lumbrokinase derived from earthworm has potential proteolytic activity and has been used to cure cardiovascular diseases since ancient times. Therefore, present study was conducted to identify remarkable chemical properties of earthworm fibrinolytic enzyme to be used commercially for treatment of stroke and myocardial infraction. We have concluded that lumbrokinase is beneficial over several other artificial fibrinolytic drugs as it is fibrin specific, inexpensive, no internal bleeding and blood loss. Most significantly, the observed characteriscts including high temperature and broad $\mathrm{pH}$ range tolerance revealed that it can be administrated orally and is efficiently absorbed by the intestinal epithelium in stable and intact form, which eliminates use of needles or surgical instruments for drug delivery. Thus, the study provides basis for extraction and purification of Lumbrokinase for its therapeutic use.

\section{Conclusion}

Lumbrokinase isolated from indigenous earthworm species was found highly stable under broad physical regimes and hence considered suitable for oral therapy in patients of cardiovascular diseases.

\section{Authors' contributions}

FA Joyia, G Mustafa and MS Khan conceived and designed the experiments, FA Joyia, MA Zia and HT Raana performed the experiments, FA Joyia and MA Zia Analyzed the data, MA Zia and MS Khan Contributed reagents/ materials/ analysis tools/facilities while FA Joyia and A Faheem wrote the paper. 


\section{References}

1. Benjamin EJ, Blaha MJ, Chiuve SE, Cushman M, Das SR, Deo R et al. (2017). Heart Disease and Stroke Statistics-2017 Update, A Report From the American Heart Association Circulation 135: 146-603.

2. Grundy SM, Pasternak R, Greenland P, Smith SJ \& Fuster V (1999). Assessment of cardiovascular risk by use of multiple-risk-factor assessment equations: A statement for healthcare professionals from the American Heart Association and the American College of Cardiology. Circulation 100: 14811492.

3. Collen D \& Lijnen H (2004) Tissuetype plasminogen activator: a historical perspective and personal account. $J$ Thromb Haemost 2(4): 541-546.

4. Furie B \& Furie BC (2008). Mechanisms of thrombus formation. $N$ Engl J Med 359: 938-949.

5. Delaney JA, Opatrny L, Brophy JM \& Suissa S (2007). Drug drug interactions between antithrombotic medications and the risk of gastrointestinal bleeding. Can Medical Assoc J 177: 347-351.

6. Vernooij MW, Haag MD, van der Lugt A, Hofman A, Krestin GP, Stricker BH \& Breteler MM (2009). Use of antithrombotic drugs and the presence of cerebral microbleeds: the Rotterdam scan study. Arch Neurol 66(6): 714720.

7. Ge T, Zhao JS, Shi HF, et al. (2005) Cloning of thrombolytic enzyme (lumbrokinase) from earthworm and its expression in the yeast Pichia pastoris. Protein Expr Purif 42(1): 20-28.

8. Tjandrawinata RR, Yunaidi DA \& Susanto LW (2016). The Safety and Tolerability of Lumbrokinase DLBS1033 in Healthy Adult Subjects. Drug Research 66(6): 293-299.

9. Cao YJ, Zhang X, Wang WH, Zhai WQ, Qian JF, Wang JS, Chen J, You NX, Zhao Z, Wu QY, Xu Y, Yuan L, Li RX \& Liu CF (2013). Oral fibrinogen-depleting agent lumbrokinase for secondary ischemic stroke prevention: results from a multicenter, randomized, parallelgroup and controlled clinical trial. Chin Med J 126: 4060-4065.

10. Wang $\mathrm{YH}$, Li SA, Huang $\mathrm{CH}, \mathrm{Su} \mathrm{HH}$, Chen YH, Chang JT \& Huang SS (2018) Sirt1 Activation by Postischemic Treatment With Lumbrokinase Protects Against Myocardial Ischemia-Reperfusion Injury. Front Pharmacol 9: 636.

11. Yan XM, Kim CH, Lee CK, Shin JS, Cho IH \& Sohn UD (2010). Intestinal absorption of fibrinolytic and proteolytic lumbrokinase extracted from earthworm, Eisenia andrei. Kor. J Physiol Pharmacol 14(2): 71-75.

12. Robbins KC \& Summaria L (1976). Plasminogen and plasmin. Methods Enzymol 45:257-273.

13. Cho IH, Choi ES, Lim HG \& Lee HH (2004). Purification and Characterization of Six Fibrinolytic Serine-Proteases from Earthworm Lumbricus rubellus. J Biochem Mol Biol. 37(2):199-205. 